\title{
Wpływ nauki na funkcjonowanie i rozwój systemu penitencjarnego w Polsce
}

\author{
TEODOR SZYMANOWSKI \\ ORCID: 0000-0002-7964-8306 \\ Wydział Prawa i Administracji \\ Akademii Ekonomiczno-Humanistycznej w Warszawie
}

1.

Na wstępie należy wyjaśnić zawarte w tytule określenia - co się rozumie pod pojęciami „wpływ nauki” i „Polska współczesna”.

Pojęcie nauki dotyczące systemu penitencjarnego obejmuje różne dyscypliny wiedzy, takie przede wszystkim jak: prawo, kryminologia, socjologia, psychiatria, psychologia, pedagogika (szczególnie resocjalizacyjna), wiedza medyczna, strategie dotyczące ochrony i bezpieczeństwa, ekonomia i zarządzanie. Oprócz tych być może niekompletnie wymienionych dyscyplin funkcjonuje też pojęcie penitencjarystyki, które najczęściej określa różne dziedziny wiedzy, ale też działalność odnoszącą się do więzień i wykonywanych środków polegających na izolowaniu osób skazanych lub podejrzanych o popełnienie przestępstwa.

Pod pojęciem Polski współczesnej rozumie się okres obejmujący lata dziewięćdziesiąte i następne od przeprowadzenia reformy prawa, a szczególnie wprowadzenia w życie nowego ustawodawstwa karnego w 1998 roku, w tym także kodeksu karnego wykonawczego. Poświęcono też kilka uwag roli i charakterowi więziennictwa w niektórych latach 
PRL (od 1945 roku), ponieważ praktyka w tej dziedzinie w Polsce różniła się znacznie od innych krajów zależnych od ZSRR, szczególnie po tak zwanym okresie stalinowskim, między innymi mniej represyjnym wykonywaniem kary pozbawienia wolności, prowadzeniem prawdziwych badań naukowych w więzieniach, przekazaniem więziennictwa w gestię Ministra Sprawiedliwości, następnie stopniowym wprowadzaniem do działalności więziennictwa międzynarodowych standardów wykonywania kar między innymi Reguł Minimalnych ONZ (niepodlegających ratyfikacji), Konwencji w sprawie zakazu tortur oraz innego okrutnego, nieludzkiego lub poniżającego traktowania albo karania, którą Polska ratyfikowała w 1989 roku. W późniejszych latach były to jeszcze Europejskie Reguły Więzienne i wiele innych dokumentów.

W 1969 roku wszedł w życie kodeks karny wykonawczy, pierwszy tego rodzaju akt w polskim systemie prawnym, w którym unormowano nie tylko przepisy dotyczące kary pozbawienia wolności, lecz także przepisy regulujące wykonywanie innych kar i środków (to jest grzywny, ograniczenia wolności, środków zabezpieczających, kar dodatkowych).

W okresie PRL w latach sześćdziesiątych i późniejszych bardzo się rozwinęło piśmiennictwo penitencjarne, w którym znalazło się również wiele rzetelnych prac naukowych, dzięki badaniom kryminologicznym (w czym najważniejszą rolę odegrał prof. S. Batawia i jego współpracownicy w Zakładzie Kryminologii PAN), a także wiele innych placówek naukowych.

\subsection{Znaczenie bibliografii w naukach penitencjarnych było istotne dla przyszłych reform}

Pragnę tu zwrócić uwagę na rolę każdej bibliografii, także tu wymienionej, dla poznania określonych zdarzeń, instytucji, osób i funkcji, które się pełni, oraz procesów, które dokonały się w przeszłości. Poszerza to nie tylko wiedzę w interesującej nas dziedzinie, ale może również odgrywać doniosłą rolę w praktycznej działalności. Tak na przykład z doświadczeń skutków wykonywania kar czy środków możemy oceniać stopień ich efektywności. Z doświadczeń wypływających ze stosowania kary pozbawienia wolności przekonujemy się, że kara izolacji nie 
przynosi pożądanych rezultatów w dziedzinie resocjalizacji (wynika to $\mathrm{z}$ amerykańskich badań, ale też z doświadczeń polskich), wynika to również z przeprowadzonych badań dotyczących recydywy przestępczej, co oczywiście nie oznacza, że kary tej nie należy stosować, ponieważ spełnia wiele rozmaitych funkcji, nie tylko polegających na wpływaniu na zachowania skazanego w przyszłości po wykonywaniu kary.

Polska bibliografia penitencjarna obejmuje zbiór opublikowanych prac w polskim piśmiennictwie w bardzo długim okresie (ponad 200 lat) i składają się na nią następujące publikacje: E. Janiszewska-Talago, Polska bibliografia penitencjarna 1795-1962, Warszawa 1963; E. Janiszewska-Talago, Polska bibliografia penitencjarna 1963-1969, Warszawa 1972; G. i J. Koreccy, Polska bibliografia penitencjarna lata 1970-2009, red. S. Lelental, Warszawa 2011; S. Lelental, A. Podziechowska, Polska bibliografia penitencjarna. Lata 2010-2011, „Przegląd Więziennictwa Polskiego" 2013, nr 80; S. Lelental, A. Podziechowska, Polska bibliografia penitencjarna. Lata 2012-2013, „Przegląd Więziennictwa Polskiego" 2014, nr 84.

Liczba pozycji w wymienionych bibliografiach przekracza 14 tysięcy. Nie wdając się w szczegółową charakterystykę tych pięciu zbiorów bibliograficznych, należy poczynić dwie uwagi. Pierwsza odnosi się do treści pozycji opublikowanych, zawartych w bibliografiach. W ścisłym znaczeniu bibliografia penitencjarna nie dotyczy tylko kar polegających na izolacji w miejscach wyodrębionych w tym celu, ale również informacji ukazujących praktykę i poglądy w dziedzinie wykonywania kar oraz innych środków stanowiących reakcje na przestępstwo lub czyny zabronione prawem (na przykład wykroczenia, środki zabezpieczające).

Druga uwaga dotyczy formy czy też rodzaju informacji zawartych w bibliografii. Mogą to być prace naukowe teoretyczne lub empiryczne (wyniki badań), dokumenty, dane statystyczne, przepisy prawa i komentarze do nich napisane, projekty przepisów, sprawozdania, wspomnienia i pamiętniki czy też dzieła literackie. I nawet jeśli wedle naszej dzisiejszej wiedzy uważa się niektóre poglądy za błędne i nie stanowią one często ważnych informacji na przykład odnośnie do okrutnego wykonywania kar — nie tylko kary śmierci — również współcześnie świat doświadczył okrutnego i nawet dokonywanego w skali masowej izolowania ludzi (w systemie niemieckich obozów koncentracyjnych czy sowieckich łagrów).

Nowa Kodyfikacja Prawa Karnego 54, 2019

(C) for this edition by CNS 
W tym tekście nie zamierzam szczególnej uwagi poświęcić roli bibliografii w naukach penalnych z jednym wyjątkiem. Chodzi tu o znaczenie prac naukowych, opublikowanych czy też dostępnych w ocenie niektórych stosowanych kar oraz ich wpływu na zmiany, co może dotyczyć reformy prawa karnego i prawa karnego wykonawczego. Tu sięgniemy do wielu przykładów wskazujących rolę nauki w proponowanych zmianach systemu kar i ich wykonywania.

Zasadnicze reformy prawa karnego zostały dokonane w latach dziewięćdziesiątych ubiegłego wieku i dotyczyły przede wszystkim trzech obszarów w dziedzinie tego prawa: prawa karnego materialnego, prawa karnego wykonawczego i prawa karnego procesowego. Te reformy umożliwiły zmiany polityczne polegające na odzyskaniu przez Polskę niezależności, ale ich pomyślne dokonanie było też możliwe dzięki istnieniu określonych niezależnych instytucji naukowych stosujących metody badawcze i zezwolenie na kontakty naukowe z krajami zachodnimi. Można tu wspomnieć o niektórych placówkach uniwersyteckich, a przede wszystkim o kierowanym zakładzie PAN przez wybitnego przedstawiciela kryminologii prof. Stanisława Batawię.

Placówka ta prowadziła wiele znaczących badań przy zastosowaniu nowoczesnej metodologii. Doniosłe wyniki badań kryminologicznych pod względem naukowym miały znaczenie dla innych placówek naukowych, na które bardzo pozytywnie oddziaływały, ale miały również pewien wpływ na praktyczne funkcjonowanie systemu karnego i penitencjarnego. Wystarczy przypomnieć, że placówki badawcze resortu sprawiedliwości często stosowały metodologię wypracowaną w Zakładzie Kryminologii PAN (na przykład w resorcie sprawiedliwości Ośrodek Badań Penitencjarnych, później Instytut Badania Prawa Sądowego czy też w Prokuraturze Generalnej Biuro Problematyki Przestępczości). Wyniki badań naukowych były publikowane w znanych czasopismach. Można tu wymienić takie szczególnie, jak: „Archiwum Kryminologii”, „Państwo i Prawo”, „Przegląd Penitencjarny” i wiele innych.

W końcowym okresie PRL (lata osiemdziesiąte) zaznaczył się wzrost aktywności społecznej, w tym wśród prawników, zwłaszcza naukowo czy społecznie zaangażowanych. W latach osiemdziesiątych powstały: Towarzystwo Naukowe Prawa Karnego, później Towarzystwo Kryminologiczne im. S. Batawii. Wcześniej, bo w 1980 roku, powstało Stowarzyszenie 
Penitencjarne „Patronat” nawiązujące do działalności dotyczącej pomocy więźniom, szczególnie politycznym („Patronat” powstał w 1909 roku, ale po drugiej wojnie światowej, do czasu jego ponownego powołania, nie działał), i które w 2010 roku obchodziło stulecie istnienia. W okresie okupacji (niemieckiej) czy prześladowań (komunistycznych) były one zakazane i rozwiązywane. $\mathrm{W}$ tych okolicznościach miały one charakter patriotyczny domagając się humanitarnego traktowania skazanych.

Innym przejawem wzrostu aktywności społecznej było powstanie w latach osiemdziesiątych i później zorganizowanego ruchu naukowego, najpierw Towarzystwa Naukowego Prawa Karnego, a następnie Towarzystwa Naukowego Kryminologii. Nie ma wątpliwości, że te inicjatywy zaistniały dzięki społecznemu ruchowi i niezależnej organizacji związkowej „Solidarności”, ogarniającej wielomilionową rzeszę Polaków. Obydwa wymienione stowarzyszenia naukowe (zwłaszcza TNPK) miały dokonać oceny polityki karnej, w tym reformy ustawodawstwa karnego. Jednocześnie TNPK zainicjowało działalność publikacyjną niezależnego czasopisma naukowego „Przeglądu Prawa Karnego”, w którym publikowano artykuły zarówno krytyczne dotyczące polityki karnej, jak i postulujące reformy prawa karnego. Niestety po kilku latach z braku odpowiednich środków finansowych zaprzestano wydawania tego czasopisma. Z biegiem lat, już w wolnej Polsce działalność wymienionych stowarzyszeń naukowych przygasła, ale w okresie zmian związanych z odzyskaniem przez państwo polskie wolności odegrały one znaczącą rolę w reformowaniu prawa w dziedzinie polityki karnej.

W pierwszym okresie przemian uchylono przede wszystkim te unormowania w zakresie prawa karnego, których nie można było tolerować w demokratycznym państwie prawnym. Do nich trzeba zaliczyć takie zmiany, jak:

- uchylenie przepisów, na mocy których można było umieszczać recydywistów w ośrodkach przystosowania społecznego (w praktyce było to przedłużenie kary pozbawienia wolności);

- likwidacja pracy operacyjnej w zakładach karnych i aresztach śledczych (w praktyce stanowiącej służbę bezpieczeństwa);

- wprowadzenie zasady humanitarnego traktowania osób pozbawionych wolności i poszanowania ich godności ludzkiej oraz wiele in- 
nych zmian łagodzących represyjność wykonywanych środków izolacji wobec wymienionej kategorii osób.

Doniosłe zmiany jeszcze przed wejściem w życie nowych kodeksów karnych wprowadzono też w k.k. Do nich trzeba zaliczyć przede wszystkim ustawowe wprowadzenie w życie za najcięższe przestępstwa kary dożywotniego pozbawienia wolności, z której zrezygnowano w k.k. obowiązującym od 1969 roku, a jednocześnie uchwalono moratorium na orzekanie kary śmierci (z której ostatecznie zrezygnowano w k.k. uchwalonym w 1997 roku).

Oczywiście zmian poprzedzających uchwalenie obowiązujących kodeksów karnych było znacznie więcej. Tu jedynie na zasadzie przykładu wspomniano o niektórych ilustrujących proces przemian prawa karnego.

Nie ma tu też potrzeby szczegółowego omawiania nawet najważniejszych zmian dokonanych w ustawodawstwie karnym w podstawowych ustawach, to jest w kodeksach i dokonanych następnie nowelizacjach, których było bardzo wiele, co zresztą niezbyt dobrze świadczy o ustawodawcy. Zmian takich po 1997 roku było w k.k. ponad osiemdziesiąt, a w k.k.w. ponad pięćdziesiąt. Oczywiście niektóre zmiany były niezbędne na przykład ze względu na międzynarodowy obrót prawny, podpisane konwencje czy też nieprzewidywalne zmiany w kraju.

Wobec istnienia w Polsce ogromnej literatury przedmiotu, podręczników, komentarzy, monografii orzecznictwa sądowego oraz innych publikacji dotyczących prawa karnego, nie ma potrzeby ani nawet możliwości dokonania choćby syntetycznego opisu systemu prawa karnego w Polsce. Natomiast w tym tekście wskazano, sięgając do wybranych przykładów, na czynniki oddziałujące na tworzenie, ale też zmiany prawa karnego. Tu odniesiono się do prawa karnego wykonawczego. Należy zacząć od odpowiedzi, na jakiej podstawie opracowano w Polsce nowy kodeks karny wykonawczy i dokonywano dalszych zmian. Decyzję w tym aspekcie podejmuje parlament, przy uwzględnieniu całej obowiązującej pod tym względem procedury, na podstawie przygotowanych projektów. Jednak w wypadku zasadniczej reformy prawa karnego, a taką było opracowanie projektów podstawowych kodeksów karnych, niezbędne było powołanie komisji kodyfikacyjnej. Efektem prac w komisji kodyfikacji karnej działającej w trzech zespołach (k.k., k.p.k., k.k.w.) było przygotowanie projektów, które zostały uchwalone przez Sejm i które weszły

Nowa Kodyfikacja Prawa Karnego 54, 2019

(C) for this edition by CNS 
w życie z dniem 1 października 1998 roku (por. ich omówienie w specjalnym numerze „Państwa i Prawa” 1998, nr 9-10, w którym znalazły się opracowania między innymi prof. K. Buchały, prof. L. Kubickiego i autora tego tekstu - dotyczące k.k.w.).

W minionym dwudziestoleciu ukazały się z pewnością setki (jeśli nie więcej) publikacji dotyczących nowego prawa karnego, w tym wykonawczego. Tu wskażemy jedynie tytułem przykładu na pozycje z literatury przedmiotu, które mogły wpłynąć na tworzenie prawa nowego. Jeszcze w latach PRL pojawiły się postulaty między innymi w środowisku naukowym domagające się głębokiej reformy więziennictwa, na przykład wprowadzenia odrębnego postępowania z więźniami politycznymi. Zostały one sformułowane na konferencji zorganizowanej w 1984 roku przez IPSiR UW, w której uczestniczyło wielu profesorów oraz innych pracowników nauki (por. Spory wokót reformy więziennictwa, red. S. Walczak, Warszawa 1985).

Ważną rolę w przygotowaniu nowego prawa karnego wykonawczego odegrał też opracowany przez A. Rzeplińskiego autorski projekt k.k.w. wydany w 1986 roku (UW). Ponadto w licznych czasopismach naukowych ukazały się publikacje drążące temat niezbędnej reformy prawa karnego („Państwo i Prawo”, „Archiwum Kryminologii”, „Przegląd Penitencjarny”, następnie „Przegląd Prawa Karnego” i „Przegląd Więziennictwa Polskiego"). Kolejnymi dokumentami, które odegrały istotną rolę w reformowaniu polskiego prawa karnego (w tym wykonawczego) były i są nadal powszechnie przyjmowane standardy międzynarodowe. Tu wskażemy nie na poszczególne dokumenty, lecz publikacje zawierające ich zbiory i wydane w języku polskim. Do nich należy zaliczyć takie publikacje, jak: B. Gronowska, T. Jasudowicz, C. Mili, Prawa człowieka, Toruń 1993; D. Gajdus, B. Gronowska, Europejskie standardy traktowania więźniów, Toruń 1998; Standardy prawne Rady Europy, red. E. Zielińska, Warszawa 1997; Międzynarodowe standardy wykonywania kar, PWP 2011, nr 72-73.

Ostatni zbiór zawiera wszystkie dokumenty międzynarodowe dotyczące wykonywania kary pozbawienia wolności.

Jeśli mówi się o wpływie publikacji na zmiany w prawie karnym, to należy wspomnieć o następującej pozycji wydanej poza oficjalnym obiegiem (bez cenzury): T. Szymanowski, Więźniowie sumienia w zakładach karnych $w$ latach osiemdziesiatych. Autor dokonał badań ankietowych na

Nowa Kodyfikacja Prawa Karnego 54, 2019

(C) for this edition by CNS 
130 osobach uwięzionych lub tymczasowo aresztowanych odnośnie do sposobu traktowania osadzonych w warunkach izolacji penitencjarnej, naturalnie już po opuszczeniu więzień, po uchyleniu stanu wojennego, wykorzystując swą pozycję członka Komitetu Prymasowskiego i kierownika Ośrodka Pomocy osobom represjonowanym przy kościele św. Krzyża w Warszawie. Tu nie miejsce, aby referować wyniki tego badania, ale warto wspomnieć, że część badanych stwierdzała życzliwy stosunek do nich ze strony funkcjonariuszy SW (około 50\%). Wspomniany artykuł został wydrukowany we Francji w języku polskim w okresie stanu wojennego, ale nieliczne egzemplarze trafiły do Polski. Dopiero w 1992 roku został on wydrukowany w „Przeglądzie Więziennictwa Polskiego" nr 2-3.

Wreszcie na ewolucję systemu penitencjarnego pewien wpływ miały eksperymenty przeprowadzone w Polsce, co zasługuje na pozytywną ocenę. Tu wspomnimy o dwóch eksperymentach omówionych w publikacjach. Pierwszy to eksperyment penitencjarny prowadzony w zakładzie karnym dla młodocianych w Szczypiornie w latach sześćdziesiątych (por. H. Świda i W. Świda, Młodociani przestępcy w więzieniu, Warszawa 1961), drugi — prowadzony w zakładzie karnym specjalnym w Oleśnicy, dotyczący stosowania środków leczniczo-wychowawczych dla wymagających tego więźniów (opisany przez M. Dworskiego i J. Kozarską, „Przegląd Penitencjarny” 1967, nr. 3).

W całym okresie PRL więziennictwo, służba więzienna i więźniowie stanowili problem nie tylko dla systemu karnego, lecz także jako środek nacisku władzy na całe społeczeństwo. To się skończyło wraz z odzyskaniem niezależności politycznej, ale problemy wiążące się z systemem penitencjarnym jako środkiem kontroli przestępczości pozostały i są nadal aktualne.

Na koniec tej części tekstu należy też zaznaczyć, że nader interesującym źródłem wiedzy dotyczącej więzień i całego systemu penitencjarnego są również wspomnienia lub pamiętniki osób izolowanych, niekiedy przez dziesięciolecia, i nierzadko są to wybitni ludzie, a wśród nich wielki i zasłużony Polak, jakim był Walery Łukasiński. W więzieniach carskich przebywał 44 lata i zmarł w twierdzy szlisselburskiej (więzienie) w 1868 roku. Jego postać znalazła odbicie w utworach Mickiewicza i Wyspiańskiego.

Nowa Kodyfikacja Prawa Karnego 54, 2019

(C) for this edition by CNS 
Autor artykułu uwzględnił w jednej ze swoich monografii (Recydywa w Polsce, 2010) trzynaście życiorysów więźniów recydywistów napisanych w wyniku konkursu, w którym znalazło się wiele informacji dających pewien wgląd również w ich przeżycia więzienne.

O wpływie nauki na system penitencjarny, między innymi autorów wymienionych wcześniej badań i piśmiennictwa, świadczy tez praca nad przygotowaniem i ostatecznym zredagowaniem projektu k.k.w., który następnie został skierowany przez rząd do Sejmu do prac ustawodawczych. W skład tego zespołu wchodzili: prof. T. Szymanowski - przewodniczący, prof. S. Lelental - zastępca przewodniczącego oraz członkowie W. Czapiewski - wicedyrektor Departamentu Legislacyjno-Prawnego, prof. Z. Hołda, prof. J. Jasiński, C. Jaworski - prezes Naczelnej Izby Adwokackiej, dr J. Korecki - płk Służby Więziennej, prof. Z. Ostrihanska, prof. S. Pawela, prof. A. Rzepliński, prof. Z Świda, płk J. Szymborski doradca dyrektora generalnego w Ministerstwie Sprawiedliwości i prof. S. Walczak. We wcześniejszej fazie prac znaczny wkład w przygotowanie projektu wnieśli płk S. Wrona (CZZK) i doc. dr S. Ziembiński - emerytowany dyrektor CZZK. Ośmielam się tu napisać, że zespół ten był kompetentny. Kilku z wymienionych członków zespołu pełniło wcześniej ważne funkcje w administracji państwowej, ale poza kompetencjami od dawna demonstrowali otwartość na postulowane zmiany w prawie karnym. Projekt spotkał się z uznaniem całej komisji do spraw reformy prawa karnego, a także świadczyły o tym niektóre opinie zagraniczne.

Jak już wcześniej zaznaczono, w latach po uchwaleniu nowego ustawodawstwa karnego dokonano licznych nowelizacji we wszystkich trzech kodeksach. Ostatnie w szerszym zakresie były wprowadzone w latach 2015-2016. Ich omówienie wraz z analizą prawną, jeśli chodzi o k.k.w., jest zawarte w publikacjach takich, jak: Kodeks karny wykonawczy. Komentarz, red. J. Lachowski, Warszawa 2016; S. Lelental, Kodeks karny wykonawczy. Komentarz, Warszawa 2016; T. Szymanowski, Prawo karne wykonawcze, Warszawa 2017.

Przedstawiciele nauki odgrywali też zasadniczą rolę w wydawaniu wznowionego w 1991 roku czasopisma naukowego (nawiązanie do przedwojennego periodyku). W jego skład wchodzili: L. Falandysz, D. Gajdus (wiceprzewodnicząca), Z. Hołda, J. Jasiński, S. Lelental, P. Moczydłowski, R. Musidłowski i profesorowie: K. Olstrowska, Z. Ostrihanska,

Nowa Kodyfikacja Prawa Karnego 54, 2019

(C) for this edition by CNS 
A. Rzepliński i T. Szymanowski (przewodniczący). Oczywiście w kolejnych latach następowały zmiany (chociażby z powodu śmierci) uzupełniane nowymi członkami zespołu redakcyjnego. Można tu wymienić między innymi prof. B. Stańdo-Kawecką, prof. Aldonę Nawój-Śleszyński, prof. T. Przesławskiego i prof. P. Stępniaka.

Niestety w ostatnim okresie kwartalnik ten przeżywa znaczne perturbacje. W zespole redakcyjnym PWP nie ma ani jednego z dawnych redaktorów i sądząc z obecnego składu (nr 95 PWP) można żywić obawy, że to zasłużone pismo straci charakter naukowy i przestanie odgrywać dotychczasową rolę, i być może zniknie z periodyków poświęconych problematyce karnej, kryminologicznej i penitencjarnej. Obiektywnie takie czasopismo jest potrzebne i moim zdaniem istnieją wystarczające warunki, aby kontynuować wydawanie PWP jako czasopisma naukowego.

2.

W drugiej części niniejszego opracowania przedstawiono wiele bardzo istotnych danych i informacji ilustrujących funkcjonowanie systemu penitencjarnego w dwóch okresach: w roku 1997 - ostatnim przed wejściem w życie nowego prawa karnego, oraz w latach 2015 i 2018 po 21 latach obowiązywania nowej kodyfikacji karnej. Najpierw trzeba wskazać na doprawdy kolosalną dynamikę zmian w stanie ujawnionej przestępczości, jakie się dokonały w latach: 1997, 2015, 2018.

Zagadnienia te wraz z próbą ich interpretacji zostały omówione w innych publikacjach autora, zwłaszcza w monografii Przestepczość $i$ polityka karna w Polsce, Warszawa 2012, i ostatnio w artykule w „Palestrze” 2018, nr 9: Zmiany w przestępczości w Polsce $w$ okresie po odzyskaniu niezależności oraz ewolucja polityki karnej $w$ tym okresie $w$ świetle danych statystycznych.

Recydywa penitencjarna (ponowne pozbawienie wolności):

- 1997 rok - 22305 (50,5\% wszystkich skazań),

- 2015 rok - 37247 (56,4\% wszystkich skazań),

- 2018 rok - 36833 (57,5\% wszystkich skazań),

— 2019 rok — 37307 (57,6\% wszystkich skazań). 
Tabela 1. Dane dotyczące osób pozbawionych wolności w latach 1997 (przed reformą prawa karnego), 2015 (przed ostatnia nowelizacją) i 2018 oraz 2019 (po dokonaniu nowelizacji w latach 2015 i 2016)

\begin{tabular}{|l|r|r|r|r|}
\hline \multicolumn{1}{|c|}{ Podstawa prawna } & 1997 & 2015 & 2018 & 2019 \\
\hline skazanie & 42978 & 65664 & 64045 & 64811 \\
\hline tymczasowe aresztowanie & 13231 & 4162 & 7360 & 8520 \\
\hline ukaranie & 1173 & 1010 & 799 & 799 \\
\hline $\begin{array}{l}\text { ogółem } \\
\text { (dane na koniec roku) }\end{array}$ & 57382 & 70836 & 7204 & 74130 \\
\hline
\end{tabular}

\begin{tabular}{|l|r|r|r|r|}
\hline \multicolumn{1}{|c|}{ Płeć } & 1997 & 2015 & 2018 & 2019 \\
\hline kobiety & 1363 & 2379 & 2940 & 2940 \\
\hline mężczyźni & 56019 & 68457 & 69264 & 70930 \\
\hline
\end{tabular}

\begin{tabular}{|l|r|r|r|r|}
\hline $\begin{array}{l}\text { Wiek osób pozbawionych } \\
\text { wolności }\end{array}$ & 1997 & 2015 & 2018 & 2019 \\
\hline do 21 lat & 7191 & 2896 & 2269 & 2104 \\
\hline 22 do 30 lat & 19234 & 21960 & 19186 & 18242 \\
\hline 31 do 63 lat & 29592 & 42827 & 48302 & 51066 \\
\hline 64 i więcej & 192 & 2203 & 1646 & 1919 \\
\hline razem & 56209 & 69826 & 7103 & 73310 \\
\hline cudzoziemcy & 1262 & 519 & 1037 & 1310 \\
\hline
\end{tabular}

Źródło: opracowanie własne na podstawie danych CZSW: https://www.sw.gov.pl/dzial/statystyka.

Komentarz do informacji zawartych $\mathrm{w}$ punkcie pierwszym tego opracowania ograniczymy jedynie do kilku kwestii, w których obserwuje się istotne zmiany, ponieważ charakterystyki osób pozbawionych wolności są uwzględniane w obszernych publikacjach kryminologicznych lub penitencjarnych.

Pierwsza dotyczy zmian w strukturze wieku osób pozbawionych wolności. Stwierdza się, że w ciągu 20 lat czterokrotnie spadł udział młodocianych wśród więźniów, a zwiększył się w starszych grupach. Jest to następstwo głębokich zmian demograficznych. $\mathrm{Z}$ dokonanych prognoz 
wynika, że te proporcje dalej się będą pogłębiać i musi to też wpływać na odpowiednie zmiany w systemie penitencjarnym.

Następna uwaga dotyczy moim zdaniem pozytywnego faktu, którym jest nikły udział cudzoziemców wśród osób pozbawionych wolności we wszystkich minionych latach. W 2018 roku odsetek ten wynosił 1,4\% ogółu pozbawionych wolności. Stanowisko autora wynika z dwóch powodów. Pierwszy to problemy ze stworzeniem odpowiednich warunków dla obcokrajowców w więzieniu, a drugi to poszanowanie prawa takich osób do przebywania we własnym kraju, blisko swojej rodziny.

W ostatnich latach w licznych krajach Europy odsetek cudzoziemców był wielokrotnie wyższy i wynosił na przykład we Włoszech - 35\%, w Belgii - 42\%, Austrii — 48\%, Grecji - 60\% i Szwajcarii - 74\%(!). Chyba ze względu na tak zwaną poprawność polityczną nie podaje się narodowości, jak też religii osób uwięzionych.

Właściwością charakteryzującą osoby pozbawione wolności jest też recydywizm. Pojęcie to ma kilka znaczeń. Najszersze to ,recydywa kryminologiczna" (nieco upraszczając, oznacza to ponowne popełnienie przestępstwa), następne recydywa „kodeksowa” (art. 64 k.k.) i recydywa penitencjarna, czyli ponowne odbywanie kary pozbawienia wolności w związku z popełnionym przestępstwem.

Z podanych wcześniej danych dotyczących liczby i odsetka takich recydywistów w całej populacji skazanych na pozbawienie wolności wynika, że nastąpił w ostatnich latach wzrost tej grupy skazanych. Świadczy to o dawno już stwierdzonej małej skuteczności tej kary (wynika to z licznych badań, na przykład w USA czy też w Polsce) w oddziaływaniu. $Z$ tego nie wynika, że nie należy się nią posługiwać w wypadku zbrodni lub niektórych czynów.

W strukturze przestępstw, za które odbywali kary w ciągu 20 lat, zauważa się znaczące zmiany. Przede wszystkim w 1997 roku w statystyce więziennej nie wykazano skazanych za przestępstwa dokonane w ruchu drogowym. Zapewne odegrała tu rolę nieznaczna liczba aut w Polsce, a ponadto słusznie nie stosowano za takie czyny kary pozbawienia wolności, inaczej niż współcześnie, to jest w 2018 roku, kiedy za przestępstwa komunikacyjne odbywało karę 5,5 tys. skazanych. Oczywiście w ruchu drogowym mogą też wystąpić poważne katastrofy lub ciężkie następstwa dla ofiar. Ale są one chyba kwalifikowane z innych artykułów.

Nowa Kodyfikacja Prawa Karnego 54, 2019

(C) for this edition by CNS 
Tabela 2. Przestępstwa popełnione przez skazanych na karę pozbawienia wolności

\begin{tabular}{|c|c|c|c|c|c|c|}
\hline \multirow{2}{*}{ Rodzaj przestępstw } & \multicolumn{2}{|c|}{1997} & \multicolumn{2}{|c|}{2015} & \multicolumn{2}{|c|}{2018} \\
\hline & lb. & $\%$ & lb. & $\%$ & lb. & $\%$ \\
\hline ogółem przestępstwa & 56209 & 100 & 67752 & 100 & 68988 & 100 \\
\hline w tym nieumyślne & 755 & 1,3 & 372 & 0,5 & 413 & 0,6 \\
\hline zabójstwo & 4292 & 7,6 & 5428 & 9 & 5542 & 8 \\
\hline $\begin{array}{l}\text { pozostałe przestęp- } \\
\text { stwa przeciwko życiu } \\
\text { i zdrowiu }\end{array}$ & 2710 & 4,8 & 4066 & 6,7 & 4131 & 6 \\
\hline zgwałcenie & 1996 & 3,6 & 2271 & 2,8 & 2274 & 3,3 \\
\hline $\begin{array}{l}\text { pozostałe przestępstwa } \\
\text { przeciwko wolności } \\
\text { seksualnej }\end{array}$ & 792 & 1,4 & 970 & 1,5 & 1364 & 2 \\
\hline niepłacenie alimentów & 3802 & 6,8 & 3015 & 4,9 & 3079 & 4,5 \\
\hline $\begin{array}{l}\text { pozostałe przestępstwa } \\
\text { przeciwko rodzinie } \\
\text { i opiece* }\end{array}$ & 2253 & 6,8 & 4154 & 6,2 & 4244 & 6,1 \\
\hline $\begin{array}{l}\text { przeciwko wymiarowi } \\
\text { sprawiedliwości }\end{array}$ & b.d & b.d & 2417 & 3,6 & 1650 & 2,4 \\
\hline kradzieże & b.d. & b.d. & 5607 & 8,3 & 4441 & 6,4 \\
\hline $\begin{array}{l}\text { kradzieże z włamaniem } \\
\text { (art. } 279 \text { k.k., art. } 208 \text { k.k. } \\
\text { z } 1969 \text { r. }\end{array}$ & 17557 & 32,3 & 11432 & 16,9 & 11649 & 16,9 \\
\hline rozbój i wymuszenia & 12850 & 22,8 & 10935 & 16,1 & 10404 & 15,7 \\
\hline $\begin{array}{l}\text { pozostałe przestępstwa } \\
\text { przeciwko mieniu }\end{array}$ & 6884 & 12,2 & 8437 & 12,4 & 9040 & 13,1 \\
\hline $\begin{array}{l}\text { razem przestępstwa prze- } \\
\text { ciwko mieniu }\end{array}$ & 37291 & 66,3 & 36411 & 53,7 & 26652 & 386 \\
\hline $\begin{array}{l}\text { przestępstwa przeciw- } \\
\text { ko bezpieczeństwu } \\
\text { w komunikacji }\end{array}$ & b.d. & b.d & 4665 & 6,9 & 5570 & 8 \\
\hline $\begin{array}{l}\text { pozostałe niewymienione } \\
\text { przestępstwa }\end{array}$ & & & & & 4317 & \\
\hline
\end{tabular}

*głównie znęcanie się

Źródło: na podstawie danych CZSW: https://www.sw.gov.pl/dzial/statystyka. 
Tabela 3. Wymiar kary pozbawienia wolności

\begin{tabular}{|c|c|c|c|c|c|c|}
\hline \multirow{2}{*}{ Wymiar kary } & \multicolumn{2}{|c|}{1997} & \multicolumn{2}{|c|}{2015} & \multicolumn{2}{|c|}{2018} \\
\hline & lb. & $\%$ & lb. & $\%$ & $\mathrm{lb}$ & $\%$ \\
\hline od 1 do 3 miesięcy & 174 & 0,4 & 584 & 0,9 & 714 & 1,2 \\
\hline powyżej 3 do 6 miesięcy & 900 & 2,2 & 4132 & 6,6 & 3860 & 6,5 \\
\hline $\begin{array}{l}\text { powyżej } 6 \text { miesięcy do } \\
\text { roku }\end{array}$ & 7666 & 18,5 & 12572 & 20,1 & 9690 & 16,6 \\
\hline $\begin{array}{l}\text { powyżej roku do roku i } 6 \\
\text { mcy }\end{array}$ & \multirow{2}{*}{11681} & \multirow{2}{*}{28,1} & 9047 & 14,7 & 6710 & 11,4 \\
\hline $\begin{array}{l}\text { powyżej roku i } 6 \text { miesięcy } \\
\text { do } 2 \text { lat }\end{array}$ & & & 10484 & 16,7 & 7410 & 12,6 \\
\hline powyżej 2 do 3 lat & 6584 & 15,8 & 8508 & 13,6 & 8829 & 15 \\
\hline powyżej 3 do 5 lat & 7528 & 18,1 & 7891 & 12,7 & 10053 & 17,1 \\
\hline powyżej 5 do 10 lat & 4551 & 11 & 4929 & 7,08 & 6727 & 11,4 \\
\hline powyżej 10 lat do 15 lat & 1772 & 4,3 & 2437 & 3,9 & 2509 & 4,3 \\
\hline 25 lat & 671 & 1,6 & 1688 & 2,7 & 1723 & 2,9 \\
\hline $\begin{array}{l}\text { dożywotnie pozbawienie } \\
\text { wolności }\end{array}$ & 7 & 0 & 363 & 0,6 & 427 & 0,7 \\
\hline razem & 41534 & 100 & 62635 & 100 & 58780 & 100 \\
\hline $\begin{array}{l}\text { średnia kara w latach po- } \\
\text { zbawienia wolności (w la- } \\
\text { tach bez kar dożywotnich) }\end{array}$ & 2,05 & - & 3,4 & - & 3,2 & - \\
\hline $\begin{array}{l}\text { skazani odbywający za- } \\
\text { stępczą karę pozbawienia } \\
\text { wolności }\end{array}$ & 1444 & & 2702 & & 4803 & - \\
\hline
\end{tabular}

Źródło: opracowanie własnena podstawie danych CZSW: https://www.sw.gov.pl/dzial/statystyka.

Wyraźnie spadła liczba przestępstw przeciwko mieniu, w tym zwłaszcza rabunków i włamań oraz niepłacenia alimentów, a zwiększyła się liczba przestępstw znęcania się. To, że w Polsce najbardziej wzrosła liczba skazań za przestępstwa drogowe, nie może dziwić, skoro liczba osobowych pojazdów samochodowych w naszym kraju przekracza obecnie liczbę $22 \mathrm{mln}$. Z danych statystyki sądowej wynika, że spadła liczba skazań za najcięższe zbrodnie, to jest zabójstwa, zgwałcenia i rozboje. Ze statystyk

Nowa Kodyfikacja Prawa Karnego 54, 2019

(C) for this edition by CNS 
penitencjarnych wynika inne stwierdzenie, ale jest to spowodowane efektem kumulacji wieloletnich skazań sprawców najcięższych przestępstw.

Z przedstawionych danych wynika, że w ostatnim okresie spadł odsetek kar relatywnie krótszych (do 2 lat pozbawienia wolności), a wzrósł odsetek kar surowszych (powyżej 3 lat pozbawienia wolności). Jednocześnie trzeba tu zaznaczyć, że od 2016 roku krótkie kary pozbawienia wolności (do roku) za zgodą sądu penitencjarnego mogą być wykonywane $\mathrm{w}$ systemie dozoru elektronicznego poza zakładem karnym (por. przepisy oddziału 2a k.k.w.). Jest to zmiana słuszna i może przynieść liczne korzyści w polityce karnej państwa. W końcu 2018 roku była to liczba znacząca, a w tym systemie odbywało karę 5014 skazanych. Można spodziewać się dobrych rezultatów tej innowacji, ale ostateczna jej ocena wymaga starannego zbadania.

\subsection{Zwolnienie skazanych z zakładu karnego po ukończeniu kary}

Zwolnienie takie może nastąpić dwojako: to jest po ukończeniu orzeczonej kary albo wcześniej na podstawie warunkowego zwolnienia. Szczegółowe omówienie tej instytucji znajduje się w piśmiennictwie. Tu podano informacje, jak to przedstawiało się w uwzględnionych trzech latach na podstawie statystyki (podano w odsetkach).

Zmiana, jaka dokonała się w ostatnich latach, jest poważnym błędem $\mathrm{w}$ polityce penitencjarnej naszego państwa w świetle nauki i doświadczeń wielu krajów, który to błąd powinien być rychło naprawiony.

Warunkowe przedterminowe zwolnienie pozwala skrócić wykonywanie kosztownej i mało efektywnej kary i jednocześnie poddanie zwolnionego warunkowo kontroli prawem przewidzianej.

Tabela 4. Zwolnienie z zakładu karnego

(koniec kary/warunkowe zwolnienie)

\begin{tabular}{|l|c|c|c|c|}
\hline \multicolumn{1}{|c|}{ Rodzaj zwolnienia } & 1997 & 2015 & 2018 & 2019 \\
\hline po ukończeniu kary & 36,6 & 69,2 & 80,4 & 84,5 \\
\hline zwolnienie warunkowe & 63,4 & 30,8 & 19,6 & 15,5 \\
\hline
\end{tabular}

Źródło: opracowanie własne na podstawie danych CZSW:

https://www.sw.gov.pl/dzial/statystyka.

Nowa Kodyfikacja Prawa Karnego 54, 2019

(C) for this edition by CNS 
Międzynarodowe standardy wręcz zalecają szerokie stosowanie tej instytucji (por. pkt 23 i 24 załącznika do rekomendacji nr R (99) 22 $\mathrm{RE}$ ), uznając warunkowe zwolnienie za jeden $\mathrm{z}$ najskuteczniejszych środków w zapobieganiu recydywie w ramach planowanej i nadzorowanej integracji ze społeczeństwem i jednocześnie przyczynia się do zmniejszenia przeludnienia więzień. Bardzo znamienne są też pod tym względem dane $\mathrm{z}$ Eurostatu sprzed kilku laty odnośnie do rozmiarów warunkowych zwolnień z wielu krajów tego regionu. Tak więc odsetek warunkowych zwolnień wynosił: w Szwecji — 79,8, Finlandii 76,4, Słowenii - 56,9, Anglii i Walii - 47,6, Austrii — 44,4, a na Litwie — 27,8, Łotwie - 22,7, w Estonii - 20,5, w Polsce (obecnie) - 19,6 oraz w Rosji - 16,4. Podążamy więc (chyba nieświadomie) drogą doświadczeń Federacji Rosyjskiej.

\subsection{Podstawowe oddziaływania na więźniów w czasie pozbawienia wolności}

Można tu uznać, że są to $\mathrm{z}$ jednej strony obiektywne warunki nie zawsze zamierzone oraz oddziaływania celowo podejmowane przez personel dozorujący i spełniający funkcje wychowawcze lub terapeutyczne. Te pierwsze to przymusowa izolacja i ograniczenia poruszania się, a także środowisko współwięźniów niejednokrotnie zdemoralizowanych. Te ostatnie okoliczności można w pewnym stopniu ograniczyć przez właściwą klasyfikację i rozmieszczenie więźniów.

Drugie oddziaływania są niezmiernie skomplikowane i niekiedy kosztowne. Będą to stosowane środki terapeutyczne lub lecznicze, angażowanie wysoko kwalifikowanych specjalistów, na przykład psychiatrów czy psychologów. Oprócz tych możliwości znane są oddziaływania szeroko dostępne i nie tak kosztowne lub trudne w realizacji. Do nich należą kształcenie i szkolenie zawodowe, a także zatrudnienie. Te pierwsze działania są adresowane przede wszystkim do młodych uwięzionych, choć szkolenie zawodowe może obejmować ludzi w pełni dorosłych. Ten rodzaj oddziaływania na młodocianych przestępców ma już za sobą ponad 200 lat tradycji. Również w Polsce przedwojennej zapoczątkowano kształcenie tej kategorii więźniów, kontynuowane po drugiej woj- 
nie światowej. Jeśli zaś chodzi o prace wykonywane przez dorosłych, to w więzieniach angielskich (wiek XVI) zapoczątkowano ten typ działania, dając uwięzionym użyteczne środki finansowe, które obecnie częściowo mogą już w zakładzie wykorzystać na zakupy, na przykład żywności, jak też wspomóc swą rodzinę. Drugie korzyści odnosi państwo, ponieważ więzień reguluje również zobowiązania finansowe (na przykład spłaca grzywnę lub inne zobowiązania).

Jeśli chodzi o pierwszą metodę aktywizacji młodocianych skazanych, czyli kształcenie, to w 1997 roku były to 3333 osoby, ale sprawozdanie roczne nie podaje, czy i ile z nich było objętych jakimkolwiek nauczaniem. W 2018 roku, czyli 20 lat później, młodocianych skazanych lub ukaranych było już tylko 790. Natomiast nauczaniem lub szkoleniem zawodowym w roku szkolnym 2017/2018 objęto łącznie 4103 więźniów, przy czym w około trzech czwartych były to kwalifikacyjne kursy zawodowe, w sprawozdaniach nie podano wieku tych kształconych osób.

Znacznie pełniejsze i bardziej optymistyczne są dane dotyczące zatrudnienia więźniów, które podjęto zaraz po drugiej wojnie światowej, z tym że w pewnej części miało ono charakter represyjny wobec osób zwalczanych politycznie (na przykład praca w kopalniach.) Po kilku latach zaprzestano takich praktyk, a więźniów angażowano do pracy na przykład w budownictwie, na drogach itp. Wykonywanie pracy należy do obowiązku skazanych, choć uwzględnia się możliwości skazanego bądź jego wnioski w tym względzie. Może też ona być wykonywana w obrębie zakładu karnego, jak i poza nim, na rzecz instytucji państwowych (także samorządowych) oraz prywatnych. Mogą to być prace wykonywane odpłatnie, jak też bez wynagrodzenia (na przykład prace na rzecz zakładu karnego). Zatrudnienie więźniów stanowi bardzo złożony problem i wymagałby on odrębnego studium. Tu ograniczono się jedynie do ilościowego aspektu tego zagadnienia. W okresie po drugiej wojnie światowej powszechność zatrudnienia osób pozbawionych wolności była w poszczególnych latach bardzo zróżnicowana, a w uwzględnionych tu okresach wynosiła: w 1997 roku - 26,1\%, w $2015-35,5 \%$ i w 2018 - 54,3\%. Trzeba podkreślić, że obecne kierownictwo więziennictwa przywiązuje dużą wagę do efektywnego i oczywiście ilościowego zwiększenia zatrudnienia osób skazanych na karę pozbawienia wolności. Trzeba też zaznaczyć, że zawsze będzie pewna liczba osób pozbawio-

Nowa Kodyfikacja Prawa Karnego 54, 2019

(C) for this edition by CNS 
nych wolności, których nie można zatrudnić (na przykład względy zdrowotne, bezpieczeństwa, brak określonych umiejętności).

\section{Uwagi końcowe}

W Europie Polska należy do państw o bardzo wysokiej liczbie osób skazanych na karę pozbawienia wolności. Jest to nieracjonalne i nieuzasadnione, ponieważ jednocześnie należymy do krajów o wyraźnie niższej przestępczości w Europie, zwłaszcza jeśli chodzi o cięższe przestępstwa (zabójstwa, zgwałcenia czy rabunki). W pewnym stopniu stanowi to rezultat unormowań w k.k., jak też nieracjonalnego orzekania kar i innych środków w reakcji na popełnienie przestępstwa między innymi z powodu braku należytej wiedzy sędziów z zakresu polityki karnej. W obydwu wypadkach można ten stan rzeczy zmienić bez ponoszenia znacznych kosztów.

Bardziej efektywne funkcjonowanie systemu penitencjarnego wymaga zmian przede wszystkim w prawie karnym materialnym w celu ograniczenia roli izolacji więziennej.

$\mathrm{Na}$ końcu odnotujmy jeden zdecydowanie pozytywny wniosek. Liczne przepisy k.k.w. gwarantują osobom pozbawionym wolności przestrzeganie ich praw zapisanych w kodeksie i jednocześnie statuują późniejszy nadzór nad ich przestrzeganiem, to jest nadzór sędziowski, administracyjny oraz kontrole RPO. Nie ma wątpliwości, że nadzór i kontrole są wykonywane, a naruszanie praw osób pozbawionych wolności nie jest częste i spotyka się ze zdecydowaną reakcją. Ten optymistyczny pogląd opieram na wnioskach pokontrolnych (CPT — międzynarodowe komisje kontroli miejsc izolacji), które kilkakrotnie wizytowały zakłady w Polsce. Można więc uznać, że pod tym względem w minionym dwudziestoleciu k.k.w. spełnił swe zadania. 


\section{The impact of science on the functioning and development of the penitentiary system in Poland}

\section{Summary}

The study is an analysis of research and teaching issues related to the penitentiary system. Reflection in this area includes various disciplines of knowledge such as law, criminology, sociology, psychiatry, psychology, pedagogy (especially social rehabilitation), medical knowledge, protection and security strategies, economics and management. The author, from the perspective of the indicated disciplines, analyzes the recent development of executive law and assesses scientific research conducted in our country.

Keywords: penitentiary system, teaching criminal law, empirical research, criminology. 